\title{
MODELING OF CALMODULIN-MEDIATED PROCESSES IN TISSUES USING CALMODULIN-FUNCTIONALIZED GOLD NANOPARTICLES AND FLUORESCENT DYES
}

\author{
MODELIRANJE INDIREKTNIH PROCESOV KALMODULINA V \\ TKIVU Z UPORABO KALMODULINA, FUNKCIONALIZIRANEGA \\ Z ZLATIMI NANODELCI IN FLUORESCENTNIMI BARVILI
}

\author{
Ketevan Chubinidze ${ }^{* 1,2}$, Besarion Partsvania ${ }^{2}$, Alexandre Khuskivadze ${ }^{3}$, \\ Paata Burnadze $^{4}$, Gia Petriashvili ${ }^{2}$, Diana Dzidziguri ${ }^{1}$, Omari Mukbaniani ${ }^{1}$ \\ ${ }^{1}$ Iv. Javakhishvili Tbilisi State University, Faculty of Exact and Natural Sciences, 1 Chavchavadze Ave., Tbilisi 0179, Georgia \\ ${ }^{2}$ Georgian Technical University, Institute of Cybernetics, Zurab Anjaparidze Street 5, Tbilisi 0186, Georgia \\ ${ }^{3}$ Tbilisi Medical State University, 33 Vazha Pshavela Ave., Tbilisi 0186, Georgia \\ ${ }^{4}$ San Diego State University, 1 Chavchavadze Ave., Tbilisi 0179, Georgia \\ Prejem rokopisa - received: 2019-04-12; sprejem za objavo - accepted for publication: 2019-10-23
}

doi:10.17222/mit. 2019.080

\begin{abstract}
We prepared and investigated a nanomaterial consisting of calmodulin functionalized with fluorescent dyes and gold nanoparticles and we have shown that calmodulin covalently linked to an excited fluorescent dye and gold nanoparticle can stimulate a surface-plasmon-coupled emission, resulting in a strong fluorescence enhancement. Herewith, calmodulin molecules were functionalized and stabilized with gold nanoparticles and fluorescent dyes in liquid and solid environments. The photo-optical properties of the proposed novel nanomaterial are promising for the development of a simple and effective method for the targeting, labelling and visualization of calmodulin-mediated processes, such as proliferation, inflammation, metabolism, apoptosis, muscle contraction, intracellular movement, etc.

Keywords: nanomaterial, calmodulin, fluorescence dye, gold nanoparticles
\end{abstract}

Avtorji so pripravili in preiskovali nanomaterial, ki je vseboval kalmodulin (vrsta znotrajcelične beljakovine), funkcionaliziran s fluorescentnimi barvili in zlatimi delci. Raziskave so pokazale, da kovalentno vezan kalmodulin, na vzbujeno fluorescenčno barvilo in nanodelce, lahko stimulira površinsko sklopljeno plazemsko emisijo, ki povzroči močno vzbuditev fluorescence. S tem so z zlatimi delci in fluorescentnimi barvili funkcionalizirali in stabilizirali molekule kalmodulina $\mathrm{v}$ tekočem in trdnem okolju. Foto-optične lastnosti predlaganega novega materiala, ponujajo možnost izboljšanja enostavne in učinkovite metode za ciljano označevanje in uravnavanje, vizualizacijo indirektnih procesov kalmodulina, kot so: proliferacija (bujna rast tkiva), vnetja, metabolizem, apoptoze (tip programirane celične smrti), mišične kontrakcije ter intracelično gibanje itd.

Ključne besede: nanomaterial, kalmodulin, fluorescentno barvilo, zlati nanodelci

\section{INTRODUCTION}

Due to their advantageous physical, chemical and biological properties, nanomaterials hold great potential in the nanomedicine area for applications in biological sensing, biomedical imaging, drug delivery and photothermal therapy. The biological activities of these structures are highly influenced by the surrounding environment that has a significant role in the designing of these materials. ${ }^{1}$ Nanoparticles can traverse through the vasculature and localize any target organ, leading to novel therapeutic, imaging and biomedical applications. ${ }^{2}$ Gold nanoparticles (GNPs) are among the most extensively studied nanomaterials. GNPs are precious metal and they have a high surface area, easy fictionalization, high electric conductivity, high stability and corrosion resistance; their pronounced plasmon-resonance band in the visible range as well as sensitivity to aggregation are

*Corresponding author's e-mail:

Chubinidzeketino@yahoo.com (Ketevan Chubinidze) among their most attractive features. ${ }^{3}$ In addition, combining the properties of GNPs with those of known organic dyes has already led to many interesting applications including sensing of biologically relevant molecules. ${ }^{4,5}$ The bioconjugation of different biological structures to nanoparticles happens through the bonding of biomolecules to nanoparticles by chemical or biological means, which render them ideal for clinical applications.

A range of functionalized groups can be attached to nanoparticles including low molecular weight ligands, peptides, proteins, polysaccharides, polyunsaturated and saturated fatty acids, DNA, plasmids, RNA, etc. ${ }^{6}$ Of particular interest are the emerging biomedical applications that directly utilize the plasmon-enhanced phenomenon for the targeting and visualization of cell proliferation, controlled by many networks of regulatory proteins. It is known that the action of calmodulin $(\mathrm{CaM})$ and $\mathrm{CaM}$-dependent signalling systems control the vertebrate cell proliferation, programmed cell death and, autophagy. ${ }^{7}$ According to the literature, in tumor and 
transformed cells, the mobilization of $\mathrm{Ca}^{2+}$ is altered, which has important implications for the tumor development and progression. ${ }^{8,9}$ Moreover, many effects of $\mathrm{Ca}^{2+}$ in cells are mediated by the binding of $\mathrm{Ca}^{2+}$ to $\mathrm{CaM}$, which causes $\mathrm{CaM}$ to bind and activate target proteins. ${ }^{10}$ Consequently, the targeting and visualization of the regions in biological tissues with an overexpressed concentration of the $\mathrm{Ca}^{2+} / \mathrm{CaM}$ complex could be a valid therapeutic approach to the targeting, labelling, and visualization of CaM-mediated processes.

The acquisition of images of biological matter using fluorescent labels and nanomaterials is generally referred to as bioimaging that forms a large field of its own. ${ }^{11}$ Actually, CaM does not absorb or emit light in the visible part of the optical spectrum. Therefore, it could be of great interest to use a nanomaterial consisting of CaM conjugated with a fluorescent dye and GNPs as the potential optical indicator used for the labelling of tissues and biological cells including cancer cells. In this work, we prepared and investigated a nanomaterial consisting of CaM functionalized with a fluorescent dye and GNPs and showed that covalent linking of CaM to the excited fluorescent dyes and GNPs can stimulate the surface-plasmon-coupled emission, resulting in a strong fluorescence enhancement.

\section{EXPERIMENTAL PART}

Colloidal monodispersed GNPs with $50 \mathrm{~nm}$ in size, with a concentration of $7.15 \times 10^{10} \mathrm{~N} / \mathrm{mL}$ and molecular weight of $196.97 \mathrm{~g} / \mathrm{mol}$ dispersed in an aqueous/citrate buffer $(0.02 \mathrm{mg} / \mathrm{mL})$, and a CaM (calmodulin bovine recombinant, expressed in $E$. coli, lyophilized powder, $\geq 98 \%$ ) with a molecular mass of $16.79 \mathrm{kDa}$, were purchased from Sigma-Aldrich. As the fluorescent dye, we used a Nile blue ( $\mathrm{Nb}$ ), (from "Exiton"). $\mathrm{Nb}$ is a cationic dye that is widely used for the labelling of biomolecules. Derivatives of $\mathrm{Nb}$ are potential photosensitizers in the photodynamic therapy of malignant tumors. This dye aggregates in the tumor cells, especially in the lipid membranes, and/or are sequestered and concentrated in the subcellular organelles. ${ }^{12,13}$ Due to the strong interaction between the $\mathrm{Nb}$ molecules and the large localized fields induced by the plasmonic coupling, a highly enhanced fluorescence is produced allowing the localization of GNP aggregates. ${ }^{14}$ The absorption and fluorescence spectra of our samples were recorded with a multi-fiber-optic spectrometer (Avaspec-2048, "Avantes"). A photoexcitation of the nanomaterials was performed with a laser light source at $\lambda=532 \mathrm{~nm}$. Imaging-based techniques, involving a fluorescence microscope (FM) and a scanning electron microscope (SEM), were used to image the prepared nanomaterials and to examine the interaction between the GNP, CaM and $\mathrm{Nb}$ constituents. To measure the decay of the fluorescence intensity with time, a Hamamatsu photomultiplier tube coupled to an oscilloscope was used.

\section{RESULTS}

In the experiments, we used the above-mentioned initial materials to prepare three separate colloidal mixtures embedded into different volumetric vials: one was filled with the $\mathrm{Nb}$ fluorescent dye dissolved in double distilled water, with a concentration of $5 \times 10^{-3} \mathrm{mg}$ $\mathrm{Nb} / 1.5 \mathrm{~mL}$ water/pH 7.5; the second one was filled with $5 \times 10^{-3} \mathrm{mg} \mathrm{Nb} / 1.5 \mathrm{~mL}$ water/1 mg CaM/1 mL water/pH 7.5 ; the third mixture consisted of $2 \times 10^{-2} \mathrm{mg}$ GNPs $/ \mathrm{mL} / 5 \times 10^{-3} \mathrm{mg} \mathrm{Nb} / 1.5 \mathrm{~mL}$ water/ $1 \mathrm{mg} \mathrm{CaM} / 1 \mathrm{~mL}$ water/pH 7.5. All the mixtures were stirred for $20 \mathrm{~min}$ at room temperature to avoid the aggregation and to obtain homogeneous solutions. The prepared liquid solutions were placed into the cuvettes having a square base $(1 \times 1 \mathrm{~cm})$ and a height of $3 \mathrm{~cm}$. In particular, one cuvette was filled with $5 \times 10^{-3} \mathrm{mg} \mathrm{Nb} / 1.5 \mathrm{~mL}$ water solution and the other two with $5 \times 10^{-3} \mathrm{mg} \mathrm{Nb} / 1.5 \mathrm{~mL}$ water/1 mg CaM/1 mL water, and $2 \times 10^{-2} \mathrm{mg} \mathrm{GNPs} / \mathrm{mL}$ $15 \times 10^{-3} \mathrm{mg} \mathrm{Nb} / 1.5 \mathrm{~mL}$ water/1mg CaM/1 mL water solution, respectively. Prepared mixtures were stored overnight at room temperature. In order to investigate the absorption and emission spectra of $\mathrm{Nb} /$ water, $\mathrm{Nb} / \mathrm{CaM} /$ water, and $\mathrm{Nb} / \mathrm{CaM} / \mathrm{GNPs} /$ water solutions, we utilized a spectrometer. In experiments, we found that the doping of $\mathrm{CaM}$ and GNPs substances in $\mathrm{Nb}$ /water solution significantly changes the absorption and emission spec-

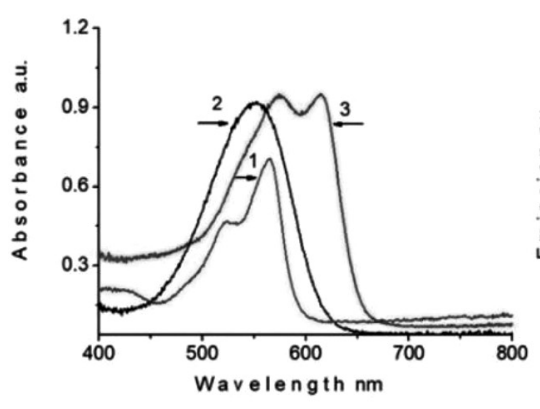

a

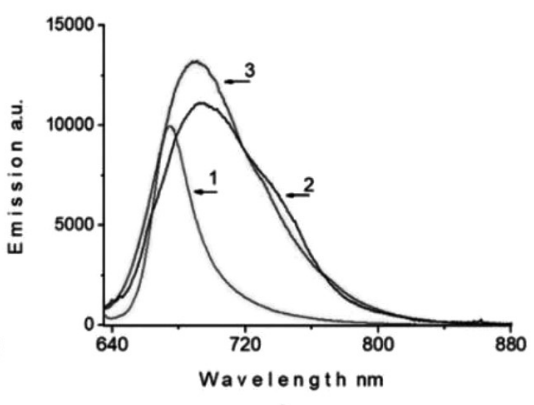

b

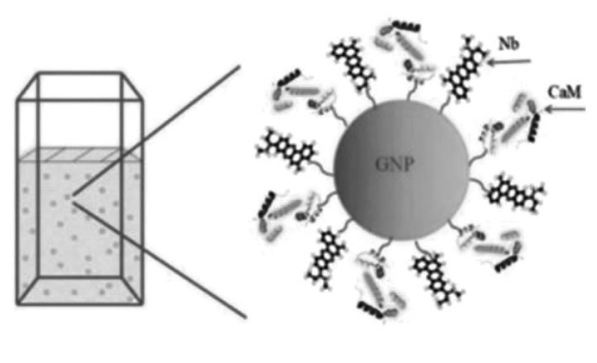

C

Figure 1: a) Absorption, b) emission, spectra of solutions: $5 \times 10^{-3} \mathrm{mg} \mathrm{Nb} / 1.5 \mathrm{~mL}$ water (1); $5 \times 10^{-3} \mathrm{mg} \mathrm{Nb} / 1.5 \mathrm{~mL}$ water/1 mg CaM/1 mL water (2); $2 \times 10^{-2} \mathrm{mg}$ GNPs/mL/5 $\times 10^{-3} \mathrm{mg} \mathrm{Nb} / 1.5 \mathrm{~mL}$ water/1 mg CaM/1 mL water (3) and c) schematic illustration of a cuvette filled with $\mathrm{Nb} / \mathrm{CaM} / \mathrm{GNPs} /$ water suspension and GNPs functionalized with $\mathrm{Nb}$ and $\mathrm{CaM}$ 


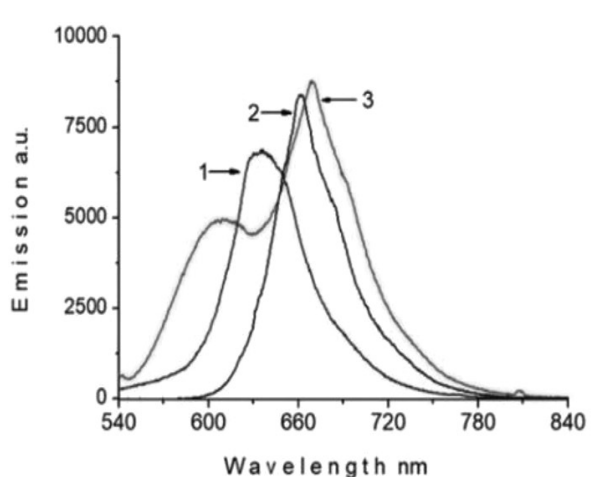

a
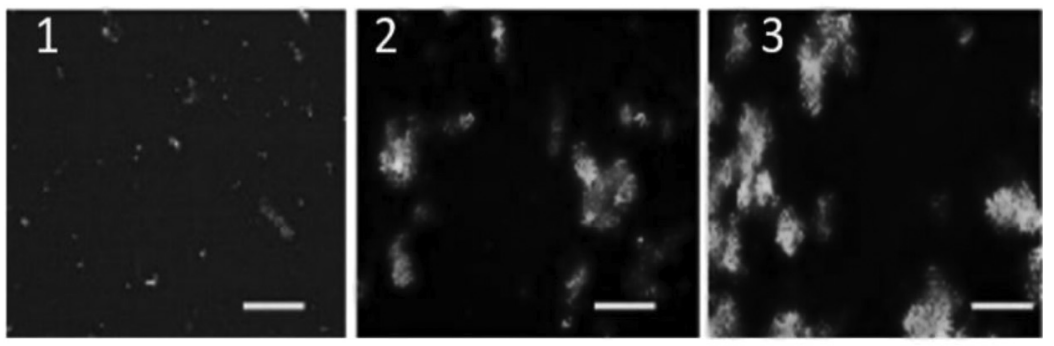

b

Figure 2: Fluorescence intensities emitted from $\mathrm{Nb}$ 1), Nb/CaM 2) and Nb/CaM/GNPs 3) clustered composites excited by the laser light source with $\lambda=532 \mathrm{~nm}$ : a), and FM images of randomly distributed nanoclusters on the glass surfaces b). The scale bar corresponds to $100 \mu \mathrm{m}$

tra of the obtained composites. As shown in Figure 1, the absorption bands of $\mathrm{Nb} / \mathrm{CaM} /$ water and $\mathrm{Nb} / \mathrm{CaM}$ / GNPs/water solutions are significantly broadened compared to the absorption band of the $\mathrm{Nb} /$ water solution. Moreover, an absorption peak of $\mathrm{Nb} / \mathrm{CaM} /$ GNPs/water solution is red shifted by $18 \mathrm{~nm}$ compared to the $\mathrm{Nb}$ /water solution. As regards the light emission, a small amount of $\mathrm{CaM}$ doped in $\mathrm{Nb} /$ water solution leads to the significant enhancement of the fluorescence emission spectrum which becomes even stronger in $\mathrm{Nb} / \mathrm{CaM} / \mathrm{GNPs} /$ water solution.

In the second part of the experiments, each solution (i.e., $\mathrm{Nb}$ water, $\mathrm{Nb} / \mathrm{CaM} /$ water, and $\mathrm{Nb} / \mathrm{CaM} / \mathrm{GNP}$ / water was extracted from the corresponding cuvette and deposited by drop-coating onto the glass slides treated with deionized water. The liquid films were stored on the substrates for $24 \mathrm{~h}$ at room temperature to let the water evaporate completely. As a result, we obtained aggregations of nanomaterials in the form of clusters on the glass substrates. To investigate the output light intensities, emitted from the $\mathrm{Nb}, \mathrm{Nb} / \mathrm{CaM}$ and $\mathrm{Nb} / \mathrm{CaM} /$ GNPs clustered composites, we used an FM equipped with a green laser light source with $\lambda=532 \mathrm{~nm}$. Fluorescence spectra were recorded using a spectrometer. Similarly to the previously described experiments, compared to the light emission from the $\mathrm{Nb}$ aggregations, in the $\mathrm{Nb} / \mathrm{CaM}$ and $\mathrm{Nb} / \mathrm{CaM} / \mathrm{GNPs}$ composites, an enhancement of the emitted light and a redshift of the fluorescence peaks were observed.

Figure 2a demonstrates the fluorescence emissions from $\mathrm{Nb}$ 1), Nb/CaM 2) and $\mathrm{Nb} / \mathrm{CaM} / \mathrm{GNPs} 3$ ) clustered composites, and Figure 2b shows the self-assembled clusters with different levels of aggregations, as seen with the FM. These self-assemblies appeared due to the dipole-dipole interactions between the nanomaterials. It should be noted that the $\mathrm{Nb}$ dyes are aggregated as small clusters, Figure 2b 1), whereas $\mathrm{Nb} / \mathrm{CaM}$ from Figure 2b 2) and the $\mathrm{Nb} / \mathrm{CaM} / \mathrm{GNPs}$ composites from Figure 2b 3) are presented as large clusters.

To visualize and identify the spatial distribution of the Nb/CaM/GNPs nanomaterials, we utilized SEM.
Figure 3 shows the location and spatial distribution of the $\mathrm{Nb} / \mathrm{CaM} / \mathrm{GNPs}$ nanomaterials.

It should be noted that the emission spectra of the $\mathrm{Nb} / \mathrm{CaM}$ and $\mathrm{Nb} / \mathrm{CaM} / \mathrm{GNPs}$ nanocomposites are in the deep-red part of the optical spectrum. Due to the reduced scattering and absorption of deep-red light in biological tissues, the proposed nanomaterial can be highly advantageous for the fluorescence image-guided techniques.

\section{DISCUSSION}

According to the Mie theory, small colloids up to 40 $\mathrm{nm}$ in diameter are expected to quench fluorescence because absorption is the dominant mechanism, while larger colloids, above $40 \mathrm{~nm}$, are expected to enhance fluorescence because scattering becomes the dominant mechanism. ${ }^{15}$ Besides, there are at least two factors that alter the fluorescence properties of a fluorescent dye in the presence of nanoparticles. These include the distance between the fluorescent dye and the nanoparticle and the orientation of the molecular dipole of the fluorescent dye in relation to the nanoparticle surface. ${ }^{16,17}$ Because of its cationic attribute, $\mathrm{Nb}$ acts as a $\mathrm{CaM}$ binding molecule.

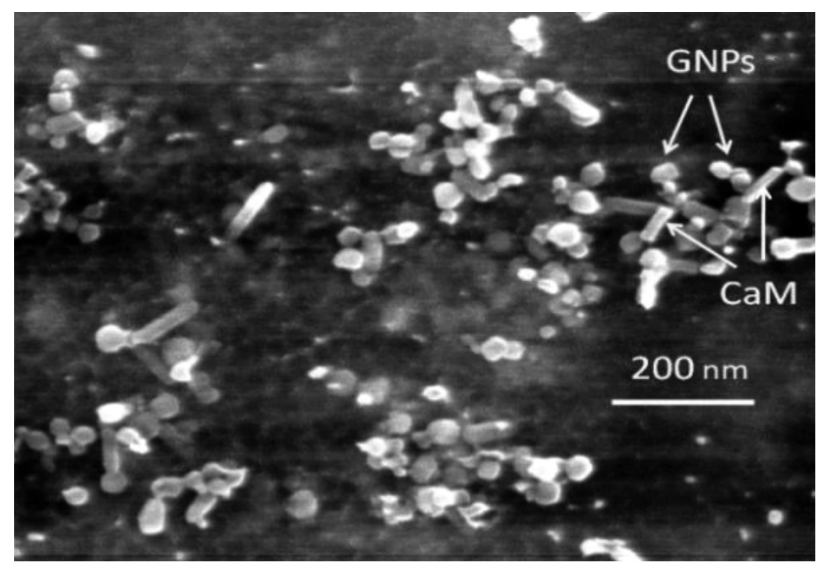

Figure 3: SEM image of Nb/CaM/GNPs nanomaterial, Nb/CaM molecules form the nanoclusters $(100-150 \mathrm{~nm})$ and are distributed in the proximity to the GNPs 
Conjugation is achieved by forming an electrostatic attraction between the $\mathrm{CaM}$ and $\mathrm{Nb}$ molecules. Upon the $\mathrm{Nb}$ binding, CaM modifies its electrostatic configuration, which results in the modification of the optical properties of $\mathrm{Nb}$ molecules. One of the most important parameters that plays a crucial role in the distance-dependent energy transfer between the acceptor and donor is the energytransfer efficiency, given with Equation (1) $E=1-\tau / \tau_{0}$, where $\tau$ and $\tau_{0}$ are the lifetimes of the donor in the presence and absence of the acceptor, respectively.

To determine the time-resolved fluorescence, the fluorescence lifetimes of the samples were measured as a function of time after being excited by a laser beam. In particular, pulsed Nd:YAG laser light of 5 nanoseconds with a wavelength of $532 \mathrm{~nm}$ was used to excite the $\mathrm{Nb} / \mathrm{CaM}$ (i.e., to determine $\tau_{0}$ ), and $\mathrm{Nb} / \mathrm{CaM} / \mathrm{GNPs}$ (i.e., to determine $\tau$ ) composites. As the detector, we utilized a Hamamatsu photomultiplier coupled to a $\mathrm{GHz}$ oscilloscope, which displayed the decay of the fluorescence intensity with respect to time. The estimated times were $\tau_{0} \approx 8,24 \times 10^{-9} \mathrm{~s}$, and $\tau \approx 1,36 \times 10^{-9} \mathrm{~s}$, respectively. The induced electric field originating from the charge separation in the nanoparticles during the plasmon-resonance oscillations is very large at very small distances from the surface. The energy-transfer efficiencies from Equation (1) can be rewritten as Equation (2): $E=R_{0}{ }^{6}$ $\left(R_{0}{ }^{6}+r^{6}\right)$. According to the measured data for the energy-transfer efficiencies from Equation (1), we found that $E=0.84$. Finally, based on the experimental results and the calculated data, we found the distance between the dye molecules $(\mathrm{Nb})$ and GNPs, which are statistically distributed on the surface, to be $R=8 \pm 0.6 \mathrm{~nm}$.

\section{CONCLUSIONS}

We prepared and investigated $\mathrm{Nb}, \mathrm{CaM}$ and GNPs based nanomaterials and demonstrated that CaM conjugated with the $\mathrm{Nb}$ fluorescent dye and GNPs can increase its fluorescence intensity upon the excitation of a pumping laser source. The obtained results can be put forward as a useful modality for the in-vitro representation of nanoparticle-mediated cancer biomarkers, cell labelling and tracking in biological tissues through fluorescence. It opens new possibilities for plasmonic applications in nanobiology and nanomedicine.

\section{Acknowledgment}

This research is based upon a grant provided by the International Science and Technology Center (ISTC), Grant \# G-2188.

\section{REFERENCES}

${ }^{1}$ M. Xu, J. Li, H. Iwai, Q. Mei, D. Fujita, H. Su, H. Chen, N. Hanagata, Formation of Nano-Bio-Complex as Nanomaterials Dispersed in a Biological Solution for Understanding Nanobiological Interactions, Scientific Reports, 406 (2012) 2, 1-6, doi:10.1038/srep00406

${ }^{2}$ F. Stanley Rosarin, S. Mirunalini, Nobel Metallic Nanoparticles with Novel Biomedical Properties, Journal of Bioanalysis \& Biomedicine, 3 (2011) 4, 085-091, doi:10.4172/1948-593X.1000049

${ }^{3}$ J. Gun, D. Rizkov, O. Lev, M. Weil, A. Poghossian, M. J. Schoning, Oxygen plasma-treated gold nanoparticle-based field-effect devices as transducer structures for bio-chemical sensing, Microchim. Acta, 164 (2009) 3, 395-404, doi:10.1007/s00604-008-0073-7

${ }^{4}$ L. Shang, Ch. Qin, T. Wang, M. Wang, L. Wang, Sh. Dong, Fluorescent conjugated polymer-stabilized gold nanoparticles for sensitive and selective detection of cysteine, J. Phys. Chem. C, 111 (2007) 36, 13414-13417, doi:10.1021/jp073913p

${ }^{5}$ J. Griffin, A. K. Singh, D. Senapati, P. Rhodes, K. Mitchell, B. Robinson, E. Yu, P. Ch. Ray, Size- and distance-dependent nanoparticle surface-energy transfer (NSET) method for selective sensing of hepatitis C virus RNA, Chem. Eur. J., 15 (2009) 2, 342-351, doi:10.1002/chem.200801812

${ }^{6}$ M. H. Jazayeri, H. Amani, A. A. Pourfatollah, H. Pazoki-Toroudi, B. Sedighimoghaddam, Various methods of gold nanoparticles (GNPs) conjugation to antibodies, Sensing and Bio-Sensing Research, 9 (2016), 17-22, doi:10.1016/j.sbsr.2016.04.002

${ }^{7}$ M. W. Berchtold, A. Villalobo, The many faces of calmodulin in cell proliferation, programmed cell death, autophagy, and cancer, Biochimica et Biophysica Acta, 1843 (2014) 2, 398-435, doi:10.1016/j.bbamcr. 2013.10.021

${ }^{8}$ G. R. Monteith, F. M. Davis, S. J. Roberts-Thomson, Calcium channels and pumps in cancer: changes and consequences, J. Biol. Chem., 287 (2012) 38, 31666-31673, doi:10.1074/jbc.R112.343061

${ }^{9}$ Y. F. Chen, Y. T. Chen, W. T. Chiu, M. R. Shen, Remodeling of calcium signaling in tumor progression. J. Biomed. Sci., 20 (2013) 23, 1-10, doi:10.1186/1423-0127-20-23

${ }^{10}$ A. Miyawaki, J. Llopis, R. Heim, J. M. McCaffery, J. A. Adams, M. Ikurak, R. Y. Tsien, Fluorescent indicators for $\mathrm{Ca}^{+}$based on green fluorescent proteins and calmodulin, Letters to Nature, 388 (1997) 6645, 882-887, doi:10.1038/42264

${ }^{11}$ O. S. Wolfbeis, An overview of nanoparticles commonly used in fluorescent bioimaging, Chem. Soc. Rev., 44 (2015) 14, 4743-4768, doi:10.1039/C4CS00392F

${ }^{12}$ J. Jose, K. Burgess, Benzophenoxazine-based fluorescent dyes for labeling biomolecules, Tetrahedron, 62 (2006) 775, 11021-11037, doi:10.1016/j.tet.2006.08.056

${ }^{13}$ C. W. Lin, J. R. Shulok, S. D. Kirley, L. Cincotta, J. W. Foley, Lysosomal localization and mechanism of uptake of Nile blue photosensitizers in tumor cells, Cancer Research, 51 (1991) 10, 2710-2719, http://cancerres.aacrjournals.org/content/51/10/2710

${ }^{14}$ R. Gary, G. Carbone, G. Petriashvili, M. P. De Santo, R. Barberi, Detection of Gold Nanoparticles Aggregation Growth Induced by Nucleic Acid through Laser Scanning Confocal Microscopy, Sensors, 16 (2016) 258, 1-11, doi:10.3390/s16020258

${ }^{15}$ H. Ghaforyan, M. Ebrahimzadeh, S. M. Bilankohi, Study of the Optical Properties of Nanoparticles using Mie Theory, World Appl. Programming, 5 (2015) 4, 79-82, ISSN:2222-2510

${ }^{16}$ M. Swierczewska, S. Lee, X. Chen, The design and application of fluorophore-gold nanoparticle activatable probes, Phys. Chem. Chem. Phys., 13 (2011) 21, 9929-41, doi:10.1039/c0cp02967j

${ }^{17}$ K. G. Thomas, P. V. Kamat, Chromophore functionalized gold nanoparticles, 36 (2003) 12, 888-98, doi:10.1021/ar030030h 